\title{
Optimization Kerosene Bio-degradation by a Local Soil Bacterium Isolate Klebsiella pneumoniae Sp. pneumonia
}

\author{
Mona Faiq Ali ${ }^{1}$, Mohanad J. M-Ridha ${ }^{1}$ and Ahmed Hussein Taly ${ }^{2}$ \\ ${ }^{1}$ Environmental Engineering college, University of Baghdad, Baghdad, Iraq. ${ }^{2}$ College of Agriculture, University \\ of Baghdad, Baghdad, Iraq.
}

\begin{abstract}
Isolated Bacteria from the roots of barley were studied; two stages of processes Isolated and screening were applied in order to find the best bacteria to remove kerosene from soil. The active bacteria are isolated for kerosene degradation process. It has been found that Klebsiella pneumoniae sp. have the highest kerosene degradation which is $\mathbf{8 8 . 5 \%}$. The optimum conditions of kerosene degradation by Klebsiella pneumonia sp. are $\mathrm{pH} 5,48 \mathrm{hr}$ incubation period, $35^{\circ} \mathrm{C}$ temperature and $10000 \mathrm{ppm}$ the best kerosene concentration. The results $10000 \mathrm{ppm}$ showed that the maximum kerosene degradation can reach $99.58 \%$ after $48 \mathrm{~h}$ of incubation. Higher Kerosene degradation which was $99.83 \%$ was obtained at pH5. Kerosene degradation was found to be maximum at $35^{\circ} \mathrm{C}$ with $98.63 \%$, where $10000 \mathrm{ppm}$ kerosene showed the highest degradation at $99.527 \%$. The results indicate that the isolated Klebsiella pneumonia sp. is extremely efficient in degrading kerosene hydrocarbons.
\end{abstract}

Keywords: Klebsiella pneumoniae sp., kerosene hydrocarbons degradation, optimum conditions, rhizodegradation.

*Correspondence: munafaiq48@gmail.com; Tel number: 07821115100

(Received: 15 September 2018; accepted: 06 November 2018)

Citation: Mona Faiq Ali, Mohanad J. M-Ridha and Ahmed Hussein Taly, Optimization Kerosene Bio-degradation by a Local Soil Bacterium Isolate Klebsiella pneumoniae Sp. Pneumonia, J Pure Appl Microbiol., 2018; 12(4):2049-2057. http://dx.doi. org/10.22207/JPAM.12.4.41

C The Author(s) 2018. Open Access. This article is distributed under the terms of the Creative Commons Attribution 4.0 International License which permits unrestricted use, sharing, distribution, and reproduction in any medium, provided you give appropriate credit to the original author(s) and the source, provide a link to the Creative Commons license, and indicate if changes were made. 


\section{INTRODUCTION}

Plant enzymes, which are exuded from the roots can be used to degrade contaminants in the soil as a bioremediation technique. It is assumed that the result of bioremediation regarding petroleum-contaminated soil is based on the stimulation of degrading microorganisms in the rhizosphere, called phytostimulation or rhizodegradation ${ }^{1}$. Biodegradation is usually considered a slow process because of the hydrophobic nature of the contaminants and consequent bioavailability limitations ${ }^{2}$. Petroleum hydrocarbons, such as diesel with n-alkane markers which range in size from $\mathrm{C} 8$ to $\mathrm{C} 25$, are highly reduced organic molecules. They may be used as a carbon source and electron donors for microorganisms to back microbial metabolism. If the molecular weight increases, the biodegradation of the hydrocarbons decreases. Microorganisms may cause degradation of the hydrocarbons with a wide range of $n$-alkanes between $\mathrm{C} 10-\mathrm{C} 35$, considering the range $\mathrm{C} 14-\mathrm{C} 19$ as the preferred ones $^{3}$. For microbial respiration, electron acceptors other than oxygen are used when the conditions are anaerobic. During the process, hydrocarbons are oxidised to intermediate molecules and then to carbon dioxide, while terminal electron acceptors are reduced ${ }^{4}$.

Rhizobacteria (RB) is defined as the bacteria that live in the surrounding area to the root or on root surface ${ }^{5}$. Boosting the degradation of the hydrocarbon can be reached through a rhizosphere effect with plants that exude organic compounds through their roots which influence the abundance, diversity, or activity of potential hydrocarbon degrading microorganisms in the zone surrounding the roots ${ }^{6}$. The best attachment sites for microorganisms are the roots. They also provide nutrients in the form of exudates which consist of organic acids and amino acids, enzymes, sugars, and complex carbohydrates ${ }^{7}$. Furthermore, Palmroth et al. ${ }^{8}$, state that root exudates from plants surely help to degrade toxic organic chemicals and acts as substrates for soil microorganisms in order to increase biodegradation rate of the organic contaminant.

Biodegradation of hydrocarboncontaminated soils which use the ability of microorganisms to degrade and/or detoxify organic contamination, has been considered as an efficient, economic, versatile and environmentally sound treatment for kerosene contaminated soils ${ }^{9-11}$. There was no microorganism located to fully degrade petroleum hydrocarbon molecule. Yet, various species or strains of the same species may have the ability of degrading different groups of hydrocarbons which are found in kerosene ${ }^{7}$. Pseudomonas, Serratia, Streptococcus, Micrococcus, Bacillus, Klebsiella, Proteus, Arthrobacter, Gordonia, Brevibacterium, Burkholderia and Mycobacterium species are located to degrade kerosene microorganisms that produce biosurfactant abound in nature. They are located in water -fresh water, groundwater, and sea- and land -soil, sediment and sludge. They can also be located in extreme environments, for example in oil reservoirs and thrive in a wide range of temperatures, $\mathrm{pH}$ values and salinity ${ }^{12}$.

They may be isolated from undisturbed environments, where they have physiological functions which do not include the solubilisation of hydrophobic pollutants, such as antimicrobial activity, biofilm formation or processes of motility, and colonization of surfaces ${ }^{13}$. Nevertheless, the most appropriate environment for widespread capability for biosurfactant production is hydrocarbon-degrading microbial communities. Some main genera which are Pseudomonas, Bacillus, Sphingomonas, Klebsiella and Actinobacteria in soils and sediments, and Pseudoalteromonas, Halomonas, Alcanivorax, and Acinetobacter in marine ecosystems generally dominated hydrocarbon -degrading bacterial populations ${ }^{14}$.

Consequently, it is expected that many biosurfactant or bioemulsifier producers belong to these same genera. It is difficult to determine an estimate of the frequency of biosurfactantproducing strains within a microbial population because it depends on the experimental procedures used. In uncontaminated soils, 2-3 $\%$ of screened populations are recorded to be biosurfactant-producing microorganisms.

In polluted soils, this figure increases to $25 \%^{14}$. Furthermore, enrichment culture techniques specific for hydrocarbon-degrading bacteria can lead to a much higher detection of biosurfactant producers with estimates up to $80 \%{ }^{15}$. Biosurfactants which are produced by microorganisms are classified into two different 
types depending on their chemical composition viz., low molecular weight surface-active agents called biosurfactants and high molecular weight biosurfactants referred to as bioemulsifiers.

The glycolipids, lipopeptides and lipoprotein, fatty acids, phospholipids, neutral lipids, particulate biosurfactants, and polymeric biosurfactant are examples of low molecular weight biosurfactants. Polysaccharides, proteins, lipopolysaccharides, lipoproteins, or complex mixtures of these biopolymers are the compositions of the high molecular weight biosurfactants. The best examined bioemulsify are the bioemulsans which are produced by different species of Acinetobacter ${ }^{16}$. Various industrial processes required different classes of biosurfactant. The consideration which was shown to the production of biosurfactants nowadays is chiefly because of their potential utilization in food processing, pharmacology, cosmetics, oil exploration and exploitation industries, environmental management, and agriculture ${ }^{17,18}$. One application of biosurfactant which is of interest to environmentalist is in environmental management and bioremediation. In the crude oil-polluted sites, biosurfactants are being used successfully in the bioremediation. In the EXXON Valdex oil spill in Alaska, Pseudomonas aeruginosa SB30 (1\%) was used to remove two times the oil on the water. The objective of this study is to determine the optimum conditions of kerosene degradation using local isolate of Klebsiella pneumonia sp. These parameters are $\mathrm{pH}$, temperature, incubation period and concentration of kerosene or concentration of cadmium.

\section{MATERIALS AND METHODS}

\section{Samples collection and bacterial isolation}

Three isolated bacterial species, including Klebsiella pneumoniae sp., Enterobacter aerogenes sp. complex and Serratia fonticola were previously isolated from barley roots contaminated with kerosene for 15 days. The isolated procedures were done in the Biology and Biotechnology Department/College of Science/University of Baghdad, Iraq. The isolates were identified previously using Epi-test and biochemical tests, and maintained on Nutrient agar medium were used, these isolates were prepared for screening experiments.
The isolates were screened for kerosene (AL-Dorah Refinery) degradation according to method described by cultures from the kerosene enriched MS media. In which, kerosene were sprayed on the surface of minimal salt (MS) agar and the bacteria were isolated by plating $(1 \mathrm{ml})$ of enriched cultures. The plates were incubated (6 days) in the dark at $28-32^{\circ} \mathrm{C}$. As culture appeared to obtain pure cultures, the colonies were intermittently transferred to fresh MS agar. Discrete bacterial colonies were isolated and subcultured onto separate agar plates on the basis of morphological observations. The pure cultures were incubated at $37^{\circ} \mathrm{C}$ for $18-24 \mathrm{hr}^{19}$.

\section{Quantitative screening}

Preparation of bacterial inoculum suspension

Isolates from a Nutrient agar stocks were inoculated into nutrient broth and incubated for $24 \mathrm{hr}$ at $30^{\circ} \mathrm{C}$ before using for tests. After incubation period, the cells in the suspension were counted by heamocytometer and the cell suspension was diluted using the same broth to obtain biomass concentration of $3 \times 10^{8} \mathrm{cell} / \mathrm{mL}$.

\section{Optimum conditions for kerosene degradation}

Optimum conditions were studied for kerosene degradation, including $\mathrm{pH}$, temperature, incubation period and concentration of kerosene.

\section{Effect of $\mathrm{pH}$ value}

To determine the influence of the initial $\mathrm{pH}$ of the culture medium, a $250 \mathrm{ml}$ Erlenmeyer flasks containing $50 \mathrm{ml}$ of the selected degradation medium was adjusted using $0.1 \mathrm{~N} \mathrm{HCl}$ or $0.1 \mathrm{~N}$ $\mathrm{NaOH}$ to give different $\mathrm{pH}$ values i.e. $\mathrm{pH} 4,5,6,7$ and 8 with 10000 ppm kerosene ${ }^{20}$.

Then the culture medium was inoculated with the selected isolate and incubated in shaker incubator (Shaker Incubator, Jissy, Korea) 150 rpm at $30^{\circ} \mathrm{C}$ for $24 \mathrm{hr}$. After the incubation, supernatant was taken from each flask and the Kerosene

Table 1. Correlation the removal of kerosene effect with variables

\begin{tabular}{lllll}
\hline & $\mathrm{T}$ & $\mathrm{Ci} \%$ & $\mathrm{pH}$ & Temp \\
\hline $\mathbf{T}$ & 1 & & & \\
$\mathbf{C i} \%$ & -0.10679 & 1 & & \\
$\mathbf{p H}$ & 0.961806 & 0.619692 & 1 & \\
Temp & 0.794058 & 0.386405 & 0.887779 & 1 \\
\hline
\end{tabular}


concentration was found by GC-FID analysis (GC System, Japane, type-5E-30).

\section{Effect of incubation time}

The best $\mathrm{pH}$ value obtained from the previous experiments was fixed to determine the optimum incubation time for the maximum Kerosene degradation, the time course for
Kerosene degradation was analyzed at $24,48,72$ and $96 \mathrm{hr}^{21}$

Degradation medium of the kerosine was prepared and inoculated with selected isolate and incubated in shaker incubator (150 rpm) at optimum $\mathrm{pH}$.

Table 2. Previous studies for bioremediation of hydrocarbon by bacteria sp.

\begin{tabular}{|c|c|c|c|c|}
\hline TPH & Condition & Bacteria sp. & Removal efficiency (\%) Ref. & \\
\hline Hydrocarbon & $\begin{array}{l}35^{\circ} \mathrm{C} \\
48 \mathrm{hr} \\
\mathrm{pH} 5.7\end{array}$ & K. pneonomiae & $60-70$ & 28 \\
\hline $\begin{array}{l}\text { Used engine } \\
\text { oil (1-6\%) }\end{array}$ & $\begin{array}{l}25-45^{\circ} \mathrm{C} \\
\mathrm{pH} 6-8\end{array}$ & $\begin{array}{l}\text { Ochrobactrum } \\
\text { anthoji } \mathrm{HM} 1 \\
\text { and } \\
\text { Citrobacter } \\
\text { freundi } \mathrm{HM} 2\end{array}$ & $\begin{array}{l}\mathrm{HM}-1, \mathrm{HM}-2 \text {, and their } 29 \\
\text { mixture efficiently } \\
\text { degraded, they achieved } 65 \\
\pm 2.2,58 \pm 2.1 \text {, and } 80 \pm 1.9 \\
\% \text {, respectively At optimum } \\
\text { conditions } \\
\mathrm{pH}=7.5, \text { temp }=37 \text { oC,UEO } \\
2 \% \text { and } 150 \text { rpm. }\end{array}$ & \\
\hline $\begin{array}{l}\text { Diesel } \\
\text { contaminated } \\
\text { soil }(1 \%-5 \%)\end{array}$ & $\begin{array}{l}25-45^{\circ} \mathrm{C} \\
\mathrm{pH} 4-11\end{array}$ & $\begin{array}{l}\text { Acinetobacter } \\
\text { baumannii }\end{array}$ & $\begin{array}{l}\text { more than } 99 \% \text { at } \mathrm{pH} 7 \text {, } \\
35^{\circ} \mathrm{C} \text {, and initial } \\
\text { hydrocarbon concentration } \\
\text { at } 4 \% \text {. degrade more than } \\
99 \% \text { of diesel oil at } \mathrm{pH} 7, \\
35^{\circ} \mathrm{C} \text { and initial } \\
\text { hydrocarbon concentration } \\
\text { of } 4 \% \text {. }\end{array}$ & 30 \\
\hline $\begin{array}{l}\text { Aromatic } \\
\text { hydrocarbon } \\
\text { Phenanthrene) }\end{array}$ & $\begin{array}{l}20-45^{\circ} \mathrm{C} \\
\mathrm{pH} 4-9\end{array}$ & Klebsiella sp & $\begin{array}{l}\text { The degradation ratio at }(400 \\
\text { ppm) was } 84.9 \%, \mathrm{pH}=7.0, \\
\left(100-600 \mathrm{ppm} \text { temperature }=30^{\circ} \mathrm{C}\right.\end{array}$ & 31 \\
\hline Crude Oil & $\begin{array}{l}20- \\
28.5^{\circ} \mathrm{C} \\
5-35 \text { days, } \\
\text { pH7-8 }\end{array}$ & $\begin{array}{l}\text { Nitrosomonas } \\
\text { and Nitrobacte } \\
r \text { species \%).The I }\end{array}$ & $\begin{array}{l}\text { The crude oil-degrading of } \\
\text { Nitrosomonas sp. was }(55.2 \\
\text { trobacter sp. with } \\
46.4 \%\end{array}$ & 32 \\
\hline Hydrocarbon & $\begin{array}{l}37^{\circ} \mathrm{C} \text {, upto } \\
15 \text { days, } \\
\text { Petroleum } \\
\text { hydrocarb } \\
\text { on(petrol/ } \\
\text { octane/die } \\
\text { sel) } 1 \%\end{array}$ & $\begin{array}{l}10 \text { types of } \\
\text { bacterial Pseudo } \\
\text { species In the }\end{array}$ & $\begin{array}{l}\text { petrol degradative as } 33 \\
\text { lonas spp. (58\%). } \\
\text { se of diesel and } \\
\text { octane degradation, Bacillus } \\
\text { spp. was more effective, } \\
79 \% \text { and } 54 \% \text { respectively }\end{array}$ & \\
\hline Hydrocarbon & $\begin{array}{l}25-45^{\circ} \mathrm{C} \\
\text { Diesel oil } \\
(\mathrm{V} / \mathrm{V}) 2 \%\end{array}$ & $\begin{array}{l}\text { Bacillus cereu } \\
s \text { DRDU1 on } \\
\text { the basis of } \\
16 \mathrm{~S} \text { rDNA }\end{array}$ & $\begin{array}{l}\text { efficiently degrading } 96 \% \text { of } \\
\text { kerosene }\end{array}$ & 34 \\
\hline $\begin{array}{l}\text { Kerosene } \\
\text { (5000ppm- } \\
60000 \mathrm{ppm})\end{array}$ & $\begin{array}{l}25-50^{\circ} \mathrm{C}, \\
24-96 \mathrm{hr}, \\
\mathrm{pH} 4-8\end{array}$ & $\begin{array}{l}\text { Klebsiella } \\
\text { pneumonia sp. }\end{array}$ & $\begin{array}{l}\text { Efficiently degrading This } \\
99.527 \% \text { at } \mathrm{pH} 5,350 \mathrm{C} \text {, study } \\
\text { kerosene con. }=10000 \mathrm{ppm}\end{array}$ & \\
\hline
\end{tabular}




\section{Effect of temperature}

Kerosene degradation was achieved at different temperatures, i.e. $25^{\circ} \mathrm{C}, 35^{\circ} \mathrm{C}, 45^{\circ} \mathrm{C}$ and $50^{\circ} \mathrm{C}^{21}$. After sterilization, the flasks were inoculated with $2 \%$ of overnight grown isolate and incubated in shaker incubator $(150 \mathrm{rpm})$ at optimum $\mathrm{pH}$ and time.

\section{Effect the concentration of kerosene}

Maximum kerosene degradation was determined by using kerosene degradation medium containing different concentrations of kerosene 5000, 10000, 20000, 30000 and $60000 \mathrm{ppm}^{22}$. The medium was inoculated with the selected isolate and in shaker incubator (150 rpm) at optimum temperature and time.

\section{RESULTS}

\section{Quantitative screening}

Three isolates were screened for their Kerosene degradation by cultivating it in Nutrient agar. The kerosene was removed by Klebsiella pneumoniae sp., Enterobacter cloacae complex and Serratia fonticola were $0.883,0.419$ and 0.835 , respectively, as in Figure 1.

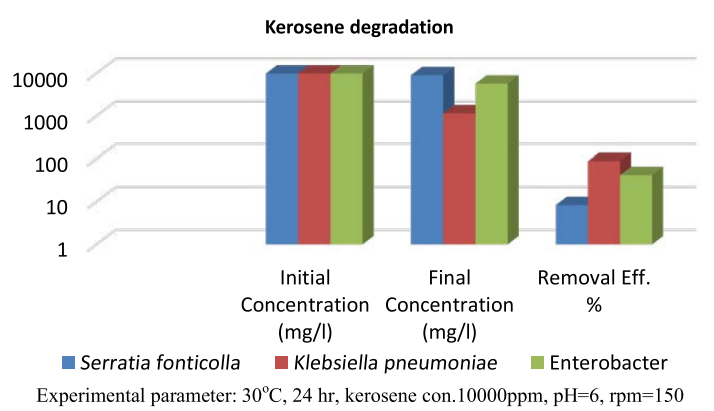

Fig. 1. Screening of isolates bacteria $\mathrm{sp}$. for kerosene degradation.

The percentage of TPH removal on each sampling day was determined by using eq. 1

Removal efficience $=\frac{\text { TPHO }- \text { TPHSD }}{\text { TPH02 }} \times 100$

Where $\mathrm{TPH}_{0}=$ total petroleum hydrocarbon on sampling day 0

sampling day

$\mathrm{TPH}_{\mathrm{SD}}=$ total petroleum hydrocarbon on

Optimum Conditions for Kerosene Degradation Effect of $\mathrm{pH}$ values
To study the effect of the initial $\mathrm{pH}$ on kerosene degradation, Klebsiella pneumonia sp. were grown on kerosene degradation medium with different $\mathrm{pH}$ values 4-8. As it can be seen in Figure 2, higher kerosene degradation 0.998 was obtained at $\mathrm{pH} 5$, while the kerosene degradation at $4,6,7$, and 8 were $0.197,0.993,0.628,0.946$ respectively. Increasing or decreasing $\mathrm{pH}$ value above or below 6 leads to reduce in kerosene degradation.

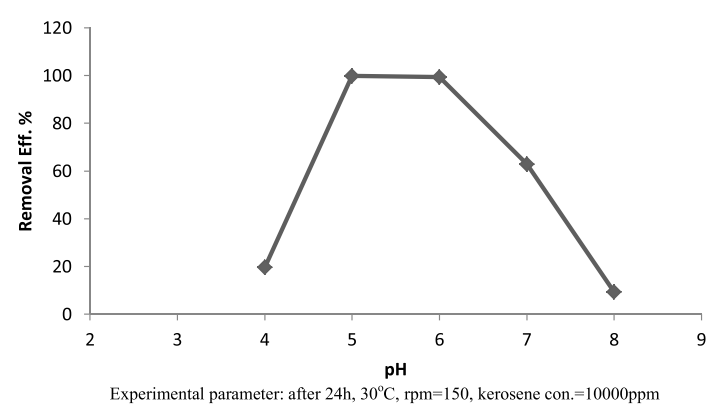

Fig. 2. Effect of initial $\mathrm{pH}$ on kerosene degradation by Klebsiella pneumonia sp.

Experimental parameter: after $24 \mathrm{~h}, 30^{\circ} \mathrm{C}, \mathrm{rpm}=150$, kerosene con. $=10000 \mathrm{ppm}$

\section{Effect of incubation periods on kerosene degradation}

Kerosene degradation reach to maximal at $48 \mathrm{~h}$ of incubation, which recorded 0.995, while the Kerosene degradation at $24 \mathrm{~h}, 72 \mathrm{~h}$ and $96 \mathrm{~h}$ were $0.45,0.984$ and 0.883 respectively as in Figure 3. Whereas, after $48 \mathrm{~h}$ of incubation, the kerosene degradation was decreased with increasing the incubation time upto $48 \mathrm{hr}$.

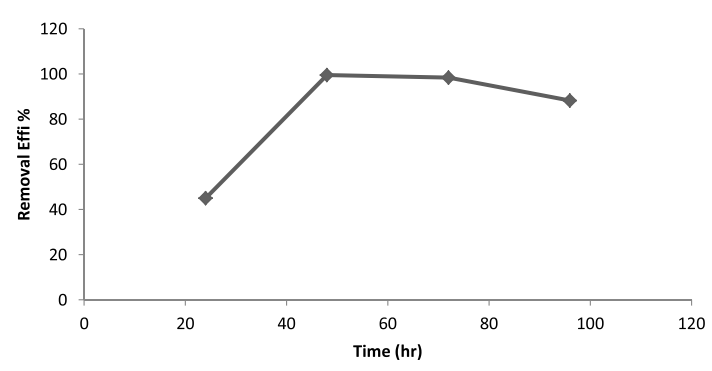

Fig. 3. Effect of incubation period on kerosene degradation from Klebsiella pneumonia sp.

Experimental parameter: $\mathrm{pH} 5,30^{\circ} \mathrm{C}, 24 \mathrm{hr}, \mathrm{rpm}=150$, kerosene con. $=10000 \mathrm{ppm}$ 


\section{Effect of temperatures on kerosene degradation}

The results in Figure 4 showed the capability of isolate Klebsiella pneumonia sp. to grow and kerosene degradation at wide range of temperatures including $25^{\circ} \mathrm{C}, 35^{\circ} \mathrm{C}, 45^{\circ} \mathrm{C}$ and $50^{\circ} \mathrm{C}$. Kerosene degradation by GC analysis was found to be maximum at $35^{\circ} \mathrm{C}$ with 0.992 , while the kerosene degradation at $25^{\circ} \mathrm{C}, 45^{\circ} \mathrm{C}$ and $50^{\circ} \mathrm{C}$ were $0.975,0.9853$ and 0.979 respectively.

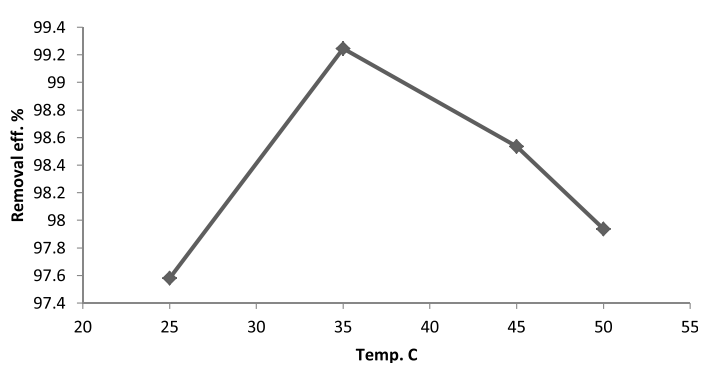

Fig. 4. Effect of temperatures on kerosene degradation from Klebsiella pneumonia sp.

Experimental parameter: $\mathrm{pH}$ 5, after $48 \mathrm{hr}, \mathrm{rpm}=150$, kerosene con. $=10000 \mathrm{ppm}$

\section{Effect the concentrations of kerosene}

To determine the ability of Klebsiella pneumonia $\mathrm{sp}$ to degrade kerosene, the total petroleum hydrocarbons were estimated at 5000ppm, 10000ppm, 20000ppm, 30000ppm and 60000ppm kerosene degradation, where $10000 p p m$ kerosene showed the highest degradation at 0.993, while the kerosene degradation at 5000ppm, 20000ppm, 30000ppm and 60000ppm were 0.973, 0.990, 0.492 and 0.103 , respectively as shown in Figure 5.

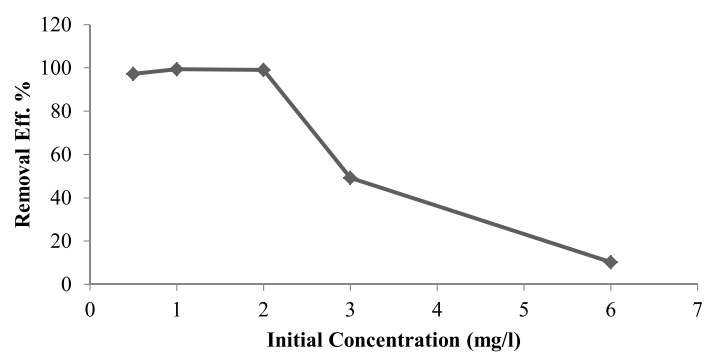

Fig. 5. Effect of concentrations of Kerosene on its degradation from Klebsiella pneumonia sp.

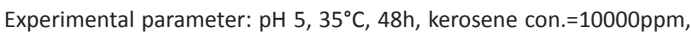
rpm $=150$

\section{DISCUSSION}

In the present study, the kerosene was removed by Klebsiella pneumoniae sp., Enterobacter cloacae complex and Serratia fonticola. In accordance with these results, the isolate Klebsiella pneumonia sp. which had the higher kerosene degradation was selected for remaining studies. The variation between members of the same species in ability for kerosene degradation may be due to the genetic variation, the type and sources of isolates and the conditions of cultivation, such as media components, temperature, $\mathrm{pH}$ and aeration and stirring, which helped to increase the ability of Klebsiella pneumonia sp. isolate to produce the enzyme in a liquid medium ${ }^{19}$.

Generally, the effect of $\mathrm{pH}$ in kerosene degradation is attributed to its role in the solubility of the medium nutritional substances, its influence on the substrate ionization and its availability for the microorganism ${ }^{23-25}$, and reported maximum biosurfactant production at below $\mathrm{pH} 7$. In present study, maximum kerosene degradation was observed at $\mathrm{pH} 5$ and $48 \mathrm{hr}$. This may be due to the change in the conditions of culture along the periods such as diminishing of oxygen, nutrients and accumulating of toxic metabolites which inhibit the bacterial growth. The incubation time plays an important role in the growth of microorganisms and kerosene degradation ${ }^{21}$. It was the found the highest kerosene degradation produced by Klebsiella pneumonia sp. at $35^{\circ} \mathrm{C}^{26}$.

The effect of temperature for growth of A. baumannii with diesel oil was evaluated. It was found that temperature is an important factor that affects the diesel degradation potential by bacteria. Mnif et al. ${ }^{27}$ found that $30^{\circ} \mathrm{C}$ was the optimum condition for the degradation of diesel by Bacillus subtilis SPB1. At the same time, the diesel oil-degrading ability of Pseudomonas $\mathrm{sp}$. strain $\mathrm{F} 4$ was reported to be $37^{\circ} \mathrm{C}^{12}$. The present study analyzed the optimum temperature for the degradation of diesel oil and it was found maximum at $35^{\circ} \mathrm{C}$. The results indicate that the Klebsiella pneumonia sp. isolated in this study are extremely efficient in degrading kerosene hydrocarbons. Our results are accordance with previous reports ${ }^{22}$. Some previous reports were also given in the Table 2. 


\section{CONCLUSIONS}

It is concluded that Secondary screening for kerosene degradation has proved that the Klebsiella pneumonia sp. provide the highest level of kerosene degradation. The optimum $\mathrm{pH}$ for kerosene degradation was 5, optimum incubation periods were $48 \mathrm{hr}$ whereas after 48 $\mathrm{hr}$ the kerosene degradation was decreased as the incubation time is increased. The optimum temperature for kerosene degradation was $35^{\circ} \mathrm{C}$ .The best kerosene concentration was $1 \%$. The results indicate that the Klebsiella pneumonia $\mathrm{sp}$. isolated in this study is extremely efficient in degrading kerosene hydrocarbons.

\section{REFERENCES}

1. Anderson, T.A., Guthrie, E.A., Walton, B.T. Bioremediation in the rhizosphere e plant roots and associated microbes clean contaminated soils. Environ Sci Technol, 1993, 27(13): e2630-e2636.

2. Mohanty, G., Mukherji, S. Biodegradation rate of diesel range $\mathrm{n}$-alkanes by bacterial cultures Exiguobacterium aurantiacum and Burkholderia cepacia. Int Biodeterior Biodegradation, 2008, 61: 240-250.

3. Liu, X., Wang, Z., Zhang, X., Wang, J., Xu, G., Cao, Z., Zhong, C., Su, P. Degradation of dieseloriginated pollutants in wetlands by Scirpus triqueter and microorganisms. Ecotox Environ Safe 2011, 74: 1967-1972

4. Morris, J. M., Jin, S., Crimi, B., Pruden, A. Review: Microbial fuel cell in enhancing anaerobic biodegradation of diesel. Chemical Engineering Journal, 2009, 146: 161-167.

5. Zhang, DC, Mortelmaier, C., Margesin, R. Characterization of the bacterial archaeal diversity in hydrocarbon-contaminated soil. Sci Total Environ., 2012, 421-422: 184-196.

6. Khan, S., Afzal, M., Iqbal, S., Khan, Q.M. Review: Plant-bacteria partnerships for the remediation of hydrocarbon contaminated soils. Chemosphere, 2013, 90: 1317-1332.

7. Huesemann, M, Hausmann, T, Fortman, $T$, Thom, R, Cullinan, V. In situ phytoremediation of PAH- and PCB-contaminated marine sediments with eelgrass (Zostera marina). Ecological Engineering, 2009, 35: 1395-1404.

8. Palmroth, MRT., Pichtel, J, Puhakka, JA. Phytoremediation of subarctic soil contaminated with diesel fuel. Bioresour Technol 2002, 84: 221-228.

9. Leahy, JG, Colwell, RR. Microbial degradation of hydrocarbons in the environment. Microbiol.
Rev., 1990, 54: 305-315

10. Margesin, R, Schinner, F. Efficiency of indigenous and inoculated cold adapted soil microorganisms for biodegradation of diesel oil in Alpine soils. App Environ Microbiol, 1997, 63(7): 2660-2664.

11. Ulrici, W. Contaminant soil areas, different countries and contaminant monitoring of contaminants, in Environmental Process II. Soil Decontamination Biotechnology, H. J. Rehm and G. Reed, Eds., 2000, 11: 5-42.

12. Chirwa EMN, Bezza FA. Petroleum hydrocarbon spills in the environment and abundance of microbial community capable of biosurfactant production. J Pet Environ Biotechnol, 2015, 6:237.

13. Van Hamme, JD, Singh, A, Ward, OP. Physiological aspects. Part 1 in a series of papers devoted to surfactants in microbiology and biotechnology. Biotechnol Adv., 2006, 24:604-620

14. Bodour, AA, Drees, KP, Rain, M, Maier, RM. Distribution of biosurfactant producing bacteria in undisturbed and contaminated arid southwestern soils. Appl Environ Microbiol., 2003, 69(6):3280-3287.

15. Rahman, KS, Rahman, T, Lakshmana, P, Perummalsamy, P, Banat, IM. Occurrence of crude oil degrading bacteria in gasoline and diesel station soils. J Bas Microbiol., 2002, 42:284-291.

16. Rosenberg, E, Ron, EZ. Surface active polymers from the genus Acinetobacter. In: Kaplan DL (ed) Biopolymers from renewable resources. Springer-Verlag, New York, 1998, 281-291.

17. Makkar, RS, Cameotra, SS. An update to the use of unconventional substrates for biosurfactant production and their new applications. Appl Microbiol Biotechnol., 2002, 58:428-434.

18. Mulligan, CN. Environmental applications for biosurfactants. Environ Poll., 2005, 133:183-198.

19. Nwinyi, OC, Victory, OF. Biodegradation of kerosene by soil bacterial species from contaminated site. CJPL, 2014, 2(1)

20. Jina, RL, Singha, P, Pandey, P. Genomic insights of aromatic hydrocarbon degrading Klebsiella pneumoniae AWD5 with plant growth promoting attributes: a paradigm of soil isolate with elements of biodegradation. 3 Biotech., 2018, 8(2): 118.

21. Nwaguma, IV, Chikere, CB, Okpokwasili, GC. Isolation, characterization, and application of biosurfactant by Klebsiella pneumoniae strain IVN51 isolated from hydrocarbon polluted soil. Bioresour. Bioprocess., 2016, 3:40.

22. Gayathiri, E, Bharathi B, Selvadhas S, kalaikandhan R. Characterisation of hydrocarbon degrading 
bacteria and its associated genes - a review. Int J Pharm Bio Sci., 2017, 8(2): (B) 1010-1019.

23. Mata-Sandoval JC, Karns J, Torrens A. Effect of nutritional and environmental conditions on the production and composition of rhamnolipids by Pseudomonas aeruginosa UG2. Microbiol Res., 2001, 155:249-256.

24. Al-Araji Y, Issa L. Biosurfactant production by Pseudomonas aeruginosa 181 Ph.D. thesis, University Putra Malaysia, 2004.

25. Kannahi M, Sherley M. Biosurfactant production by Pseudomonas putida and Aspergillus niger from oil contaminated site. Inter J Chem Pharm Sci., 2012, 3(4):37-42.

26. Chander S, Lohitnath CR, Mukesh T, Kumar DJ, Kalaichelvan PT. Production and characterization of biosurfactant from Bacillus subtilis MTCC441 and its evaluation to use as bioemulsifier for food bio-preservative. Adv App/ Sci Res., 2012, 3(3):1827-1831.

27. Mnif I, Sahnoun R, Ellouze-Chaabouni S, Ghribi D. Evaluation of $B$. subtilis SPB1 biosurfactants' potency for diesel-contaminated soil washing: optimization of oil desorption using Taguchi design. Environ Sci Pollut Res., 2014, 21:851-861.

28. Nwakanma, C, Obih, EC, Onyia, O. Molecular identification of bacteria involved in degradation of crude oil. Nig J. Biotech., 2016; 31:1-8.
29. Ibrahim HMM. Biodegradation of used engine oil by novel strains of Ochrobactrum anthropi HM-1 and Citrobacter freundii HM-2 isolated from oilcontaminated soil. 2016, 3 Biotec., 6:226

30. Palanisamy N., Ramya J, Kumar S, Vasanthi NS, Chandran P, Khan S. Diesel biodegradation capacities of indigenous bacterial species isolated from diesel contaminated soil. J Environ Health Sci Eng., 2014, 12:142.

31. Fouda A, El-Gamal MS, Alemam A, Hassan SED, Desouky SE. Biodegradation of Phenanthrene by Klebsiella sp isolated from organic contaminated sediment. J Adv Bio Biotechnol., 2015, 4(4):1-12.

32. John RC, Okpokwasili GC. Crude oil-degradation and plasmid profile of nitrifying bacteria isolated from oil-impacted mangrove sediment in the Niger delta of Nigeria. Bull Environ Contam Toxicol., 2012, 88(6):1020-1026.

33. Islam SMS and Rahman T. Assessment of hydrocarbon degradability of the bacterial species isolated from different oil contaminated sites of Bangladesh. Environ Sci. Ind J. 2017; 13(4):141.

34. Debajit BR, Yadav NS. Bioremediation of petroleum based contaminants with biosurfactant produced by a newly isolated petroleum oil degrading bacterial strain. Egypt. J. Petrol., 2017, 26(1):181-188. 
Supplementary Figure 1. Gas chromatography of kerosene degradation analysis.

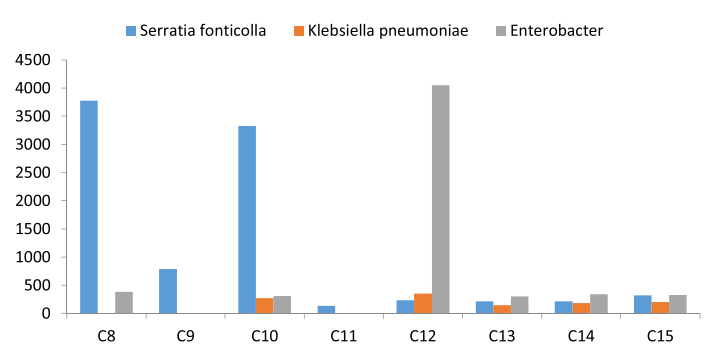

a. TPH chromatograms for effect of different bacteria $\mathrm{sp}$. in optimum treatment

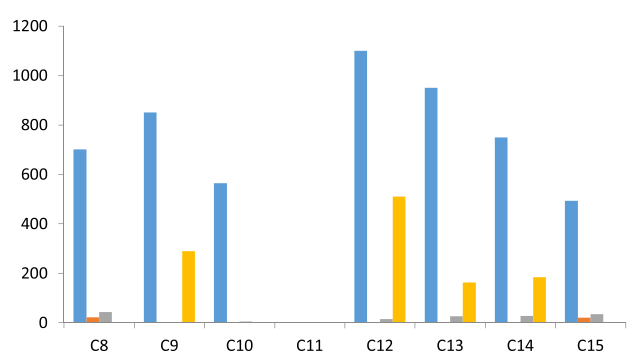

c. TPH chromatograms for effect of different incubation time in optimum treatment

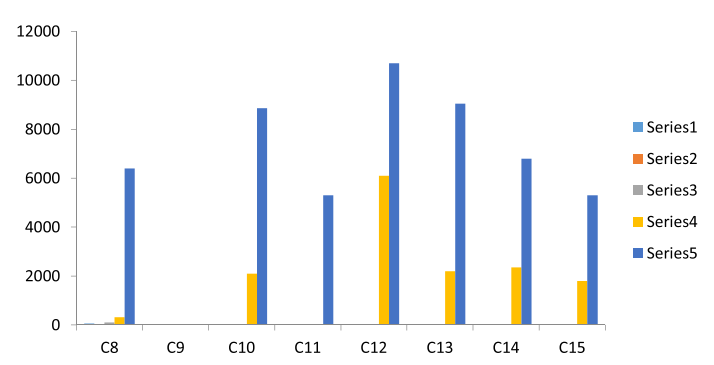

e. TPH chromatograms for effect of different concentration of kerosene) in optimum treatment

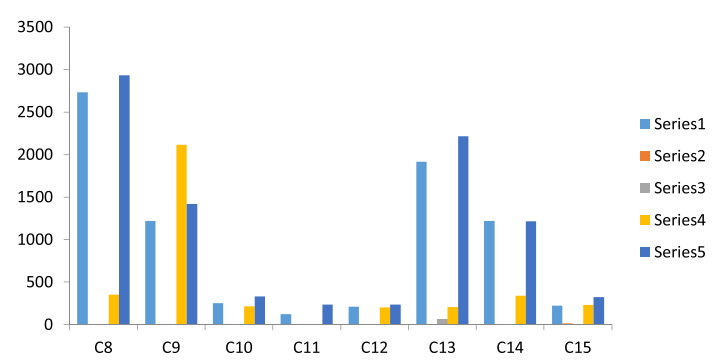

b. TPH chromatograms for effect of different $\mathrm{pH}$ in optimum treatment

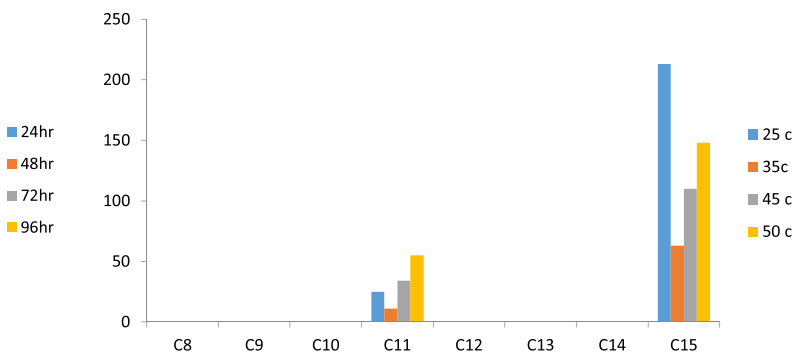

d. TPH chromatograms for effect of different temperature in optimum treatment 